\title{
An Application of the "Efficiency Gap" Measure to Redistricting in Oregon
}

\author{
Priscilla L. Southwell ${ }^{1}$ \\ ${ }^{1}$ Department of Political Science, University of Oregon, Eugene, USA \\ Correspondence: Priscilla L. Southwell, Department of Political Science, University of Oregon, Eugene, Eugene, \\ OR 97403, USA. Tel: 541-232-4205. E-mail: psouth@uoregon.edu
}

Received: October 25, 2017

Accepted: November 20, 2017

Online Published: November 29, 2017

doi:10.5539/jpl.v10n5p152

URL: https://doi.org/10.5539/jpl.v10n5p152

\begin{abstract}
This is a preliminary application of McGhee and Stephanopoulos's efficiency gap measure to the state of Oregon for elections from 2012-2016. This is one of the measures currently being considered by the U.S. Supreme Court in the Gill v. Whitford gerrymandering case. Our results suggest that the current configuration of U.S, House districts minimizes the impact of a sizeable statewide Republican vote (@41-42\%) that results in only 20\% of the seats being given to this party. This disparity is less apparent in state senate and house seats, although the Democratic Party was at a distinct disadvantage in 2016 state senate elections. We also note the growing number of uncontested elections since this redistricting plan was first adopted in 2012.
\end{abstract}

Keywords: gerrymander, redistricting, efficiency gap, Gill v. Whitford

\section{Introduction}

The "First Monday in October" has come and gone, and the U.S. Supreme Court has now heard oral arguments in the case of Gill vs. Whitford, No. 16-1161. This decision is not likely to be handed down for several months. However, the justices, especially Justice Anthony M. Kennedy appeared to be paying close attention to this gerrymandering case, on appeal from Wisconsin. Justice Kennedy, a key swing vote on this court, has already indicated an inclination toward addressing partisan gerrymandering in Vieth v. Jubelirer (2004), but also emphasized the need for a standard for determining when partisan gerrymandering has gone too far and risks being declared unconstitutional.

The three-judge Federal District Court panel ruled earlier this year that the Republicans in Wisconsin had exceeded the boundaries of conventional partisan gerrymandering. Judge Kenneth F. Ripple, writing for the majority, stated that the Wisconsin redistricting district plan

“...was designed to make it more difficult for Democrats, compared to Republicans, to translate their votes into seats" (Liptak and Shear, 2017, p. A19). This was the first federal court decision in over 30 years that rejected a redistricting plan as partisan gerrymandering (Liptak and Shear, 2017).

\section{The "Efficiency Gap"}

Among the various standards being considered in this case is the "efficiency gap" - a measure developed by Eric McGhee and Nicholas Stephanopoulos (2015). Although other measures, such as "median-mean comparison, have been promoted as alternatives (Krasno et al., 2016; Tam Cho, 2017), the efficiency gap was the one that was used by the plaintiffs in the Gill v. Whitford case (McGhee, 2017a). McGhee (2017b) also notes that the efficiency gap is a measure, not a test, and a good legal test may need to include several measures that reflect other values and principles, in addition to efficiency.

The efficiency gap centers upon the large numbers of votes that are "wasted" in single-member districts. That is, some voters cast their ballots for losing candidates, while others vote for candidates who win but are in excess of the needed margin of victory. The former type of wasted votes increases in "cracked" districts, where one party uses the gerrymander to distribute the opposition party's likely voters over several districts in order to reduce their chances of capturing a seat. The latter type of wasted votes is increased by "packing" the opposition party's likely voters into one or several districts to limit their impact in adjacent districts. This system is inefficient if a particular redistricting plan results in a much larger number of wasted votes for one party over the other, as the election can then result in a discrepancy between the statewide partisan vote and the partisan distribution of seats 
in the state legislature or congressional delegation. Such was the result in the 2012, 2014, and 2016 state legislative elections in Wisconsin, where the Democratic candidates won the statewide vote, but never held more that 39 of the 99 seats in the state's Assembly, prompting the current Gill v. Whitford case (Wines, 2017).

\section{Empirical Analysis}

The efficiency gap is a simple, easily-computed measure; it is "the difference between the parties' respective wasted votes, divided by the total number of votes cast in the election" (Stephanopoulos and McGhee, 2015, p. 851). Table I shows how this measure can be calculated for a hypothetical district plan. The result is that there are 200 fewer wasted votes (out of a total of 1000 votes) for Party A than for Party B, resulting in an efficiency gap of 20 percent that favors Party A (Stephanopoulos and McGhee, 2015, p. 852).

Table 1. Calculation of the efficiency gap

\begin{tabular}{ccccccccc}
\hline & \multicolumn{2}{c}{$\begin{array}{c}\text { Total Votes } \\
\text { by Party }\end{array}$} & \multicolumn{2}{c}{$\begin{array}{c}\text { Lost Votes } \\
\text { by Party }\end{array}$} & \multicolumn{2}{c}{$\begin{array}{c}\text { Surplus Votes } \\
\text { by Party }\end{array}$} & \multicolumn{2}{c}{$\begin{array}{c}\text { Wasted Votes } \\
\text { by Party }\end{array}$} \\
\hline District & A & B & A & B & A & B & A & B \\
\hline 1 & 70 & 30 & 0 & 30 & 20 & 0 & 20 & 30 \\
2 & 70 & 30 & 0 & 30 & 20 & 0 & 20 & 30 \\
3 & 70 & 30 & 0 & 30 & 20 & 0 & 20 & 30 \\
4 & 54 & 46 & 0 & 46 & 4 & 0 & 4 & 46 \\
5 & 54 & 46 & 0 & 46 & 4 & 0 & 4 & 46 \\
6 & 54 & 46 & 0 & 46 & 4 & 0 & 4 & 46 \\
7 & 54 & 46 & 0 & 46 & 4 & 0 & 4 & 46 \\
8 & 54 & 46 & 0 & 46 & 4 & 0 & 4 & 46 \\
9 & 35 & 65 & 35 & 0 & 0 & 15 & 35 & 15 \\
10 & 35 & 65 & 35 & 0 & 0 & 15 & 35 & 15 \\
Total & 550 & 450 & 70 & 320 & 80 & 30 & 150 & 350 \\
\hline
\end{tabular}

Source: Stephanopoulos and McGhee (2015), p. 852.

At first blush, this calculation seems to require the rather cumbersome task of summing all the wasted votes in each district. However, Stephanopoulos and McGhee (2015) note that assuming that all districts are equal in population and include only two parties allows for a much simpler formula:

$$
\text { Efficiency Gap }=\text { Seat Margin }-(2 \times \text { Vote Margin })
$$

"Seat Margin" is the share of all seats held by a particular party, minus 50 percent. "Vote Margin" is the share of the statewide votes received by this party, minus 50 percent). As Stephanopoulos and McGhee show by applying this to the hypothetical data of Figure 1, Party A received 55 percent of the statewide vote, but captured 80 percent of the 10 seats. The efficiency gap is therefore $20 \%$ or $[(80 \%-50 \%)-2 \times(55 \%-50 \%)]$

Stephanopoulos and McGhee (2015) proposed a threshold for the efficiency gap of two seats for congressional districts and eight percent for state house districts. They analyzed congressional district and state house elections from 1972 to 2012, although they confined themselves to states with at least eight congressional districts. They conclude that, in general, the typical redistricting plan did not give an advantage to one party over another. However, they found that in recent years, particularly in the 2012 elections, the efficiency gaps favoring the Republican party have increased.

\section{Analysis of Oregon}

The following section is an analysis of the U.S. house, Oregon state senate, and Oregon state house elections from 2012-2016, using McGhee and Stephanopoulos's efficiency gap measure. This is an updated version of McGhee and Stephanopoulos's (2015) analysis of state legislative seats, but it also applies this test to the U.S. House races - unexamined by these authors. The results are shown in Table 2 below. 
Table 2. Efficiency gap analysis of Oregon U.S. House, State Senate \& State House Races, 2012-2016

\begin{tabular}{ccccc}
\hline $\begin{array}{c}\text { Election Type } \\
\text { (\# of Seats) }\end{array}$ & Democratic \% of Seats & Democratic \% of Statewide Vote & EG* & No. of Uncontested Races \\
\hline 2012 U.S. House (5) & $80.0 \%$ & $58.0 \%$ & $14.0 \%$ & 0 \\
2014 U.S. House (5) & $80.0 \%$ & $57.2 \%$ & $15.7 \%$ & 0 \\
2016 U.S. House (5) & $80.0 \%$ & $58.4 \%$ & $13.2 \%$ & 1 \\
2012 State Senate (16) & $50.0 \%$ & $51.5 \%$ & $-3.0 \%$ & 1 \\
2014 State Senate (16) & $75.0 \%$ & $62.5 \%$ & $-13.2 \%$ & 7 \\
2016 State Senate (16) & $43.8 \%$ & $53.5 \%$ & $4.5 \%$ & 4 \\
2012 State House (60) & $56.6 \%$ & $51.1 \%$ & $4.5 \%$ & 12 \\
2014 State House (60) & $56.6 \%$ & $51.1 \%$ & $1.2 \%$ & 22 \\
2016 State House (60) & $58.3 \%$ & $53.6 \%$ & & 1 \\
\hline
\end{tabular}

*Positive \% indicates advantage for Democratic candidates

These results suggest that the current configuration of U.S, House districts in Oregon minimizes the impact of a sizeable statewide Republican vote. The consequence is that the Republican Party hold only $20 \%$ (1 of 5) of the U.S. House seats, despite its candidates receiving @ 42-43\% of the statewide. Although McGhee and Stephanopoulos's (2015) argue for 2-seat difference as an inefficient gap for U.S. House races in larger states, this figure appears a bit high for smaller states such as Oregon. One could easily argue that the Republicans in Oregon were due an additional U.S. House seat in all three of these most recent elections. However, to fix this "inefficiency, " a substantial change would be required in at least one existing Democratically-held district such that it included more likely Republican voters. This is unlikely to happen in a Democratically-controlled state legislature, as has been the case in Oregon over the last decade. This disparity is less apparent in state senate and house seats, although the Democratic Party is at a distinct disadvantage in the recent 2016 state senate elections.

This phenomenon has been a characteristic of the state of Oregon for several years. Although its federal and statewide offices are currently dominated by the Democratic Party, Oregon remains a politically competitive state because its partisan divisions are geographic in nature. The Republican Party often secures a sizeable number of rural state house and senate seats, as is true elsewhere in the nation. However, most of Oregon's population is concentrated west of the Cascade Mountains, and has tended to favor the Democratic Party. This western portion of the state, particularly the Portland metropolitan area and several university communities to the south (Eugene, Corvallis, Ashland), has grown in population over the past decades, as these communities have been attracting younger professionals. In contrast, the eastern portion of the state is characterized by high-plains farming and ranching, and has a distinctly Republican preference.

We also note the growing number of uncontested elections, since the redistricting plan was first adopted in 2012. This suggests that both parties may have tested the waters in 2012 in newly-created districts, but have conceded certain districts to their opposition in subsequent elections. These results also underscore the possibility of bipartisan "packing," as both parties have simply claimed certain geographical areas as fiefdoms. Both the Portland metropolitan area and these eastern counties of Oregon are the areas most likely to have these uncontested seats noted in Table 2. And party competition and voter choice go down the drain in the process. This one of main limitations to the efficiency gap, as noted by Tam Cho (2017). She argues that bipartisan gerrymandering can produce a small efficiency gap, because both parties agree to create safe seats for each other. As she states: "The map is 'fair' to both parties, giving them both advantages, while being simultaneously unfair and severely disadvantageous to the electorate" (p. 36).

Redistricting has been a controversial process in Oregon from the onset. In 1961, the state legislative district lines were redrawn for the first time since 1911. The involvement of the secretary of state in the redistricting process has proven necessary, as the legislature has often been unsuccessful in completing this redistricting process, including in the 1991 and 2001 legislative sessions.

Recent redistricting battles have arisen primarily because of the strong regional divide between the parties and the shifts in the state's population, as described above. The population of eastern Oregon has declined relative to the rest of the state, although many out-of-state retirees have recently moved to Deschutes (Bend) and Jackson 
(Ashland) counties and therefore have slowed this trend. While state law says that the legislature cannot draw lines for partisan advantage, redistricting is routinely driven by partisanship. With the parties battling to protect or even expand their seats while trying to address the population shifts, redistricting has become a difficult and controversial process. In addition, the powerful role played by the secretary of state has also fueled the fires of the debate over redistricting.

The redistricting process starts in the state legislature early in the year following the national census, which is conducted at the beginning of each decade. The legislature has until July 1 to adopt new district boundaries. If the legislature is successful at this task, the proposed for the new districts goes to the governor, who has until August 1 to sign or veto the proposal. If the governor concurs, the plan goes into effect for the upcoming elections, unless legal challenges are filed.

If the legislature fails to meet the July 1 deadline, or if the governor vetoes the redistricting bill, then the next step in the process differs between state legislative and congressional district plans. When the legislature is unable to agree on a legislative districting plan, or if the governor vetoes the legislature's plan, then the secretary of state becomes responsible for drawing the new legislative boundaries. When the legislature is unable to pass a bill redrawing congressional district lines, or if the governor vetoes the legislature's proposal, then the federal courts have responsibility for drawing the new district lines. The final redistricting plan for state legislative seats must be completed by December 15 of the year following the national census. No deadline exists for congressional redistricting, although noncompliance by the next primary season would invite court challenges.

While the legislature is assigned the primary duty of redistricting under current law, the state supreme court has the authority to review the redistricting plan at each stage of the process. When legal challenges are filed against redistricting plans, they are sent directly to the state supreme court for judicial review. If the supreme court determines that a plan does not comply with constitutional requirements, the plan is declared void, with specific references to the areas of noncompliance. The plan is then usually referred to the secretary of state for revision. If the legislature's plan is voided, the secretary of state must draft a redistricting of the state legislative districts, conduct a public hearing, file a transcript of the hearing, and file a corrected redistricting plan with the supreme court by November 1 of this same year. The Court may order additional corrections; otherwise the new plan becomes operative on November 15.

The role of the Oregon Supreme Court in redistricting is not only defined by the Oregon Constitution, but also constrained by the Fourteenth Amendment to the U.S. Constitution, which requires state legislative districts be equal in population when drawn. The Oregon Supreme Court also evaluates redistricting plans according to the criteria described in Oregon Revised Statutes, and the secretary of state's Administrative Rules. The supreme court must provide written opinions. (Oregon State Legislature, 2012).

Because of the political and legal battles that have characterized the redistricting process in recent decades, several attempts have been made to reform it. Anticipating that Oregon might gain a U.S. House seat after the 2010 census, and perhaps frustrated with the stagnated reform efforts in the 2007 and 2009 legislative sessions, proponents of redistricting reform used the petition initiative to attempt put a measure on the 2010 ballot. This proposal would have created a nonpartisan redistricting commission made up of five retired judges, one from each congressional district - a reform that Stephanopoulos (2016), Lindgren and Southwell (2013), and others have found to increase partisan fairness.

However, this reform effort was unsuccessful after about 10 percent of the signatures gathered by the chief sponsor, "Common Sense for Oregon," were deemed invalid by the secretary of state's office (Melton, 2010), Similarly, in 2011, a joint resolution was introduced in the state legislature to amend the Oregon Constitution and establish a panel of 24 retired judges, or what were called "special masters," to create state legislative and congressional redistricting plan after each census - an extension and elaboration of the proposed ballot measure of 2010. This resolution died in a legislative committee. Thus, despite the controversies surrounding redistricting, the process has remained generally unchanged since 1952. Perhaps the Gill v. Whitford case will change all of this.

\section{Implications}

Writing in the Fall of 2017, the decision on Gill v. Whitford will not come for several months, and the outcome is uncertain. Yet, even if the outcome is that a gerrymandering standard such the efficiency gap is not accepted by the Supreme Court, this measure would continue to be useful in the upcoming years. As states use the 2020 Census Bureau data to redraw district lines, the efficiency gap measure will provide a measure that could help the state legislature and governor, as well any redistricting commission, ward off the inevitable charges of partisan gerrymandering, and even lawsuits, if these officials attempt to follow its parameters. 


\section{References}

Bedock, C., Bol, D., \& Ehrhard, T. (2017). Political scientists and electoral reforms in Europe and Canada: What they know, what they do. Election Law Journal: Rules, Politics, and Policy, 16, 335-340. https://doi.org/10.1089/elj.2017.0445

Best, R. E., Donahue, S. E., Krasny, J., Magleby, D. B., \& McDonald, M. D. (2017). Considering the prospects for establishing a packing gerrymanderings standard. Election Law Journal: Rules, Politics, and Policy, ahead of print. https://doi.org/10.1089/elj.2016.0392

Caughey, D., Tausanovitch, C., \& Warshaw, C. (2017). Partisan gerrymandering and the political process: Effects on roll-call voting and state policies. Election Law Journal: Rules, Politics, and Policy, ahead of print. https://doi.org/10.1089/elj.2017.0452

Chen, J. (2017). The impact of political geography on Wisconsin redistricting: An analysis of Wisconsin's Act 43 Assembly Districting Plan. Election Law Journal: Rules, Politics, and Policy, ahead of print.https://doi.org/10.1089/elj.2017.0455

Chen, J., \& Rodden, J. (2015). Cutting through the thicket: Redistricting simulations and the detection of partisan gerrymanders. Election Law Journal: Rules, Politics, and Policy, 14, 331-345.

Kason, J. S., Marley, D., McDonald, M., Donahue, S., \& R.E. Best. (2016). Can gerrymanders be measured? An examination of Wisconsin's state assembly. Retrieved from https://ssrn.com/abstract=2783144

Lindgren, E., \& Southwell, P. L. (2013). The effect of redistricting commissions on electoral competitiveness in U.S. House elections, 2002-2010. Journal of Politics and Law, 6, 13-18.

Liptak, A., \& Shear, M. (2017). Top court puts gerrymandering on unclear path. The New York Times, October 4, 2017, A1 \& A19.

McGhee, E. (2017a). Measuring efficiency in redistricting. Election Law Journal: Rules, Politics, and Policy, ahead of print. http://doi.org/10.1089/elj.2017.0453

McGhee, E. (2017b). Symposium: The efficiency gap is a measure, not a test. SCOTUSblog. Retrieved from http://www.scotusblog.com/2017/08/symposium-efficiency-gap-measure-not-test/

Melton, K. (2010). Restricting initiative comes up short. Oregonian, July 27, p. A1.

Oregon State Legislature. (2012). Legislative Committee Services. Background brief on redistricting, September 12, https://www.oregonlegislature.gov/citizen_engagement/Reports/Redistricting.pdf

Stephanopoulos, N. (2016). Arizona and anti-reform. University of Chicago Legal Forum 477; U of Chicago, Public Law Working Paper No. 520. Retrieved from https://ssrn.com/abstract $=2551556$

Stephanopoulos, N. O., \& McGhee, E. M. (2015). Partisan gerrymandering and the efficiency gap. The University of Chicago Law Review, 82, 831-900.

Tam Cho, W. K. (2017). Measuring partisan fairness: How well does the efficiency gap guard against sophisticated as well as simple-minded modes of partisan discrimination? University of Pennsylvania Law Review, 1-20. Retrieved from https://www.pennlawreview.com/online/166-U-Pa-L-Rev-Online-17.pdf

Wines, M. (2017). Justices face Wisconsin case that could redraw partisan political maps. The New York Times, October 2, A16.

\section{Copyrights}

Copyright for this article is retained by the author(s), with first publication rights granted to the journal.

This is an open-access article distributed under the terms and conditions of the Creative Commons Attribution license (http://creativecommons.org/licenses/by/4.0/). 